\title{
PROBLEMATIKA PEPENDIDIKAN ISLAM DALAM RUMAH TANGGA DI DESA MORELLA KABUPATEN MALUKU TENGAH
}

\author{
Saida Mailet \\ IAIN Ambon \\ saida.manilet@iainambon.ac.id
}

\begin{abstract}
This study aims to reveal: 1) The form of Islamic education for children in households in Morella village, Central Maluku district, 2) Constraints and solutions adopted in the implementation of Islamic education in households in Morella village, Central Maluku Regency. This study uses a descriptive qualitative research method with a phenomenolological approach with data collection procedures, namely observations related to forms of Islamic education for children in the household, and interviews related to the obstacles found by parents in educating children with Islamic education and the solutions made. Data collection procedures are carried out by collecting data related to forms of Islamic education in the household, presenting data that is included in the focus of the study and making conclusions. The results found: 1) the form of Islamic education in the household includes faith education, including: a) Opening the life of a child with the sentence Laa Ilaaha Illallaah, by various ways of tending the child at birth, child technique, breastfeeding a child, cutting / shaving hair or aqiqah, circumcision, b) introduce halal and haram, andc) reading the Qur'an. Education in aspects of worship include: a) Teaching Salat,b) fast and c) give alms. Education in moral aspects includes: a) Prohibition of traveling and b) Behaving honestly. Education in social aspects: a) Do good to parents, b) Maintain friendship with relatives, c) Do good to neighbors,d) Respect for older people, e) Ethics of greeting, f) Ethics of eating and drinking, andg) Meet friend's invitation.
\end{abstract}

\section{Keywords: Form of Islamic Education for Children, Household}

Abstrak:Penelitian ini bertujuan untuk mengungkapkan: 1) Bentuk pendidikan Islam bagi anak dalam rumah tangga di desa Morella kabupaten maluku tengah, 2) Kendala dan solusi yang ditempuh dalam pelaksanaan pendidikan Islam dalam rumah tangga di desa Morella Kabupaten Maluku Tengah. Penelitian ini menggunakan metode penelitian deskriptif kualitatif dengan pendekatan fenomenolologis dengan prosedur pengumpulan data yakni observasi terkait bentuk-bentuk pendidikan islam bagi anak dalam rumah tangga, dan wawnacara terkait kendala yang ditemukan orang tua dalam mendidik anak dengan pendidikan Islam serta solusi yang dilakukan. Prosedur pengumpulan data dilakukan dengan pengumpulan data terkait bentuk-bentuk pendidikan islam dalam rumah tangga, kemudian display data yang masuk dalam fokus penelitian hingga penarikan kesimpulan. Hasil penelitian ditemukan: 1) bentuk pendidikan Islam dalam rumah tangga meliputi pendidikan keimanan, meluputi: a) Membuka kehidupan anak dengan kalimat Laa Ilaaha Illallaah, dengan berbagai cara mengazani anak saat lahir, mentahnik anak, menyusui anak, menggunting/mencukur rambut atau aqiqah, khitan, b) mengenalkan halal dan haram, dan c) membaca Al-Qur'an. Pendidikan dalam aspek ibadah meliputi: a) Mengajarkan Shalat, b) berpuasa dan c) memberi zakat.Pendidikan dalam aspek moral meliputi: a) Larangan bepergian dan b) Berperilaku jujur. Pendidikan dalam aspek sosial: a) Berbuat baik kepada orang tua, b) Menjaga silaturahmi dengan sanak saudara, c) Berbuat baik kepada tetangga, d) Menghargai orang yang lebih tua, e) Etika memberi salam, f)Etika makan dan minum, dan g) Memenuhi undangan teman

Kata kunci: Bentuk Pendidikan Islam Bagi Anak, Rumah Tangga 


\section{PENDAHULUAN}

Dalam ajaran Islam, manusia diciptakan sebagai khalifah di muka bumi.Karena itu untuk menjalankan tugas ini, manusia dibekali beberapa potensi, yakni jasmani, rohani, dan akal (Shihab, 2007: 372-374).Atas dasar inilah, maka pendidikan harus diupayakanmengarah pada tujuanpenciptaan tersebut, sehingga setiap potensi individu dapat tumbuh berkembang dengan wajar sebagai hamba Allah maupun sebagai khalifah-Nya.Akhir dari tujuan pendidikan Islam terletak pada terlaksananya pengabdian yang penuh kepada Maha Pencipta, baik pada tingkat individu, kelompok, maupun kemanusiaan dalam arti yang seluasluasnya (Nata, 2010: 62).

Sejalan dengan harapan akhir dari pendidikan Islam di atas, Sisitem Pendidikan Nasional di Indonesia juga memiliki fungsi dan tujuan yang sama, sebagaimana tertuang dalam UU Nomor 20 Tahu 2003:

Pendidikan nasional berfungsi mengembangkan kemampuan dan membentuk watak serta peradaban bangsa yang bermartabat dalam rangka mencerdaskan kehidupan bangsa, bertujuan untuk berkembangnya potensi peserta didik agar menjadi manusia yang beriman dan bertakwa kepada Tuhan yang Maha Esa, berakhlak mulia, sehat, berilmu, cakap, kreatif, mandiri dan menjadi warga negara yang demokratis serta bertanggung jawab (DEPDIKNAS, 2011: 7).

Rumusan tersebut menggambarkan kriteria manusia Indonesia yang ingin dicapai mencakup: 1) manusia religius, 2) manusia bermoral/berakhlak mulia, 3) manusia pencinta ilmu, 4) manusia yang cakep, 5) manusia yang penuh krativitas, 6) manusia yang mandiri/tidak bergantung dan manja, 7)manusia yang perduli terhadap kepentingan masyarakat, bangsa, dan negara, dengan jiwa demokratis dan tanggung jawab yang tinggi untuk membawa bangsa Indonesia mencapai cita-cita idealnya (Daulay, 2004: 198-199). Tujuh kriteria tersebut merupakan tipe manusia ideal yang ingin dibentuk oleh negara Indonesia melalui pengembangan potensi diri dalam proses pendidikan.

Membahas tentang pendidikan tentu tidak telepas dari jalur atau lembaga berlangsungnya proses pendidikan itu. Undang-Undang RI No. 
20 Tahun 2003 tentang SISDIKNAS pada Bab VI pasal 13 disebutkan bahwa, jalur pendidikan terdiri atas pendidikan formal, nonformal, dan informal yang dapat saling melengkapi dan memperkaya (DEPDIKNAS, 2011: 12). Pendidikan formal berlangsung di sekolah, pendidikan nonformal berlangsung di masyarakat, dan pendidikan informal berlangsung dalam keluarga. Lembaga yang dijadikan fokus kajian ini ialah lembaga pendidikan informal, yakni pendidikan dalam lingkungan rumah tangga dengan orang tua sebagai aktor pendidik utama (Room, 2010: 178).

Kegiatan pendidikan dalam rumah tanggaadalah kegiatan pendidikan tanpa suatu organisasi yang terstruktur dan ketat, tanpa adanya program waktu yang terjadwal, dan tanpa adanya evaluasi.Namun, pendidikan informal tetap memberikan pengaruh kuat terhadap pembentukan kepribadian seorang anak (Ahmadi, 2003: 169). Sanapiah Faisal (t.th: 67) dengan hal senada juga menyatakan bahwa pendidikan keluarga sama sekali tidak terorganisasi secara struktural, tidak terdapat kronologi perjenjangan, tetapi lebih merupakan hasil pengalaman belajar individual/mandiri, dan pendidikannya tidak terjadi di dalam "medan interaksi belajar mengajar buatan" sebagaimana pada pendidikan sekolah dan di masyarakat. Ini menunjukkan bahwa pendidikan dalam rumah tangga meskipun tidak tersusun secara struktural, namun berdampak besar bagi pembentukan kepribadian anak. Pendidikan dalam rumah tangga tidak mengenal setinggi apa pangkat dan jabatan orang tua, namun merupakan sebuah kewajiban yang wajib ditunaikan terhadap anak .

Karenapendidikan dalam keluarga memiliki nilai strategis dalam pembentukan kepribadian anak, maka keteladanan yang diberikan dan bagaimana kebiasaan hidup orang tua sehari-hari dalam rumah tangga akan mempengaruhi perkembangan jiwa anak itu. Keteladanan dan kebiasaan yang ditampilkan orang tua dalam bersikap dan berperilaku tidak akan terlepas dari perhatian dan pengamatan anak, dan kebiasaan 
orang tua ini kemungkinana besar akan ditiru dan menjadi pandangan hidup anak. Sikap meniru ini dalam ilmu psikologi dikenal dengan istilah imitasi.

Dari didikan orang tua, anak mampu membedakan antara yang baik dan yang buruk, dan mereka tidak akan sembarangan terjerumus dalam perbuatan-perbuatan yang dapat merugikan dirinya maupun orang lain (Daradjat, 2005: 66). Harapantersebut akan mudah terwujud apabila orang tua melakukan bimbingan kepada anak-anaknya dengan penuh tanggung jawab.

Hal inilah yang kemudian Allah peringatkan kepada setiap pendidik untuk berhati-hati meninggalkan anak-anak yang lemah, dan ini berarti ada keharusan bagi orang tua untuk berusaha menyiapkan anak-anaknya menjadi generasi yang kuat, seperti yang tercantum dalam Q.S. alNisa>'/4: 9 sebagai berikut:

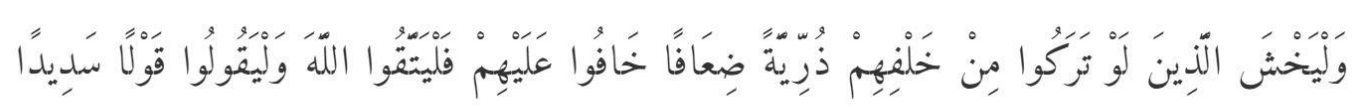

Terjemahnya:

Dan hendaklah takut kepada Allah orang-orang yang seandainya meninggalkan di belakang mereka anak-anak yang lemah, yang mereka khawatir terhadap (kesejahteraan) mereka.Oleh sebab itu hendaklah mereka bertakwa kepada Allah dan hendaklah mereka mengucapkan perkataan yang benar.

Ayat di atas menunjukkan betapa besarnya perhatian Islam terhadap anak.Islam pun lantas dengan tegas menginstruksikan kembali kepada orang tua untuk mendidik dan mengasuh anak-anaknya dengan optimal.

Ada kecenderungan di beberapa negara majuakhir-akhir untuk menjadikan lingkungan keluarga kembali sebagai basis bagi pendidikan anak dengan semboyan "back to family", keluarga dihidupkan kembali perannya dalam pembentukan watak dan kepribadian anak seta pengembangan nilai-nilai moral. Gerakan ini dimaksud untuk kembali 
mencari keseimbangan dalam tata kehidupan masyarakat.Langkah kembali kepada keluarga merupakan solusi yang praktis terhadap berbagai persoalan kemasyarakatan yang terjadi, yang tidak mudah diatasi jika diserahkan sepenuhnya kepada institusi di luar keluarga (AlMunawwar, 2005: 7-8). Kenyataan ini menjadi bukti betapa pentingnya keluarga terhadap pembentukan kepribadian anak, sehingga meskipun ada institusi lain selain keluarga, akan tetapi keluarga tetap harus difungsikan sebagai lembaga utama dalam pendidikan anak. Karena hasil pendidikan anak dalam keluarga itulah yang menjadi cermin bagi masyarakat.

Penjelasan di atas merupakan sebuah fenomena yang sebagaimana juga terjadi di Desa Morella Kabupaten Maluku Tengah.Secara umum, suasana keagamaan dalam masyarakat di desa ini terlihat begitu antusias dalam melaksanakan ajaran-ajaran agama Islam.Kerukunan di antara warga serta hubungan sosial yang baik merupakan ciri khas tersendiri yang dimiliki oleh komunitas desa ini.Di desa ini terdapat beberapa lembaga pendidikan Islam, yakni sekolah dasar hingga menengah seperti MI, MTs, dan MA sebagai lembaga pendidikan formal, dan beberapa taman pengajian al-Qur'an, majelis ta'lim serta organisasi kemasyarakatan lainnya yang berperan sebagai lembaga pendidikan nonformal.

Lingkungan masyarakat yang agamis dengan adanya lembagalembaga pendidikan Islam harusnya menghadirkan anak-anak di desa ini sebagai anak yang rajin menjalankan perintah agama. Namun pada kenyataannya apa yang dilakukan anak dalam kehidupan sehari-hari masih jauh dari ajaran agama. Hal ini terlihat dalam pengamatan bahwa masih ada anak yang malas melaksanakan kewajiban agama, seperti ibadah shalat lima waktu, malas membaca al-Qur'an, terjadinya pergaulan bebas di antara remaja, dan kurangnya etika baik kepada orang tua maupun orang lain. 
Lembaga pendidikan formal dan nonformal sekalipun telah terorganisasi dengan visi yang jelas, namun kedua lembaga tersebut dalam menjalankan fungsinya terlihat belum menuai hasil yang maksimal bagi kehidupan beragama anak di Desa Morella Kabupaten Maluku Tengah. Hal ini tentunya tidak bisa terlepas dari peranan lembaga pendidikan informal, artinya orang tua sebagai pendidik pertama dalam pembentuk pribadi yang baik bagi anak harus turut serta menempatkan posisi dalam proses pendidikan Islam, apalagi saat diamati dengan saksama,anak lebih banyak memiliki waktu bersama orang tua ketimbang waktu anak di sekolah, maka kesibukan orang tua di rumah bukanlah sebuah alasan untuk tidak sempat mendidik anak, seperti perhatian, kontrol dan koreksi terhadap perilaku mereka, sehingga peran orang tua dapat mendukung keberhasilan pendidikan yang dijalankan oleh sekolah dan masyarakat. Dengan demikian, krisis iman, kurangnya moral dan kurangnya jiwa sosial pada diri anak dapat diantisipasi.

Bertolak dari pemikiran di atas yang kemudian menempatkan pendidikan Islam dalam rumah tangga sebagai bagian terpenting dalam proses transformasi nilai dan sikap yang bermuara pada terbentuknya anak yang memiliki kekuatan iman dan takwa serta memiliki moral yang baik dan jiwa sosial yang sesuai dengan harapan, khususnya di Desa Morella Kabupaten Maluku Tengah. Dengan demikian maka penelitian ini penting dilakukan guna mengetahui bentuk pendidikan Islam apa saja yang dilakukan oleh orang tua kepada anaknya dalam rumah tangga serta kendala dan solusi yang ditempuh.

\section{METODE}

Metode yang digunakan dalam penelitian ini adalah metode penelitian kualitatif dengan pendekatan fenomenologis.Tujuan penggunaan pendekatan fenomenologis dalam penelitian ini adalah untuk mencari dan menemukan makna dari hal-hal yang esensial atau mendasar dari fenomena atau fakta yang terjadi di lapangan terkait 
dengan pendidikan Islam bagi anak dalam rumah tangga di Desa Morella Kabupaten Maluku Tengah. Adapun prosedur pengumpulan dilakukan adalah dengan cara observasi langsung tentang bentuk pendidikan islam bagi anak dalam rumah tangga, wawancara terkait kendala dan solusi yang dilalui orang tua, dan dokumentasi proses pendidikan Islam bagi anak. Untuk mendapatkan hasil penelitian yang Reliabel, peneliti menggunakan beberapa prosedur analisis data, yakni reduksi data, yaitu mengumpulkan data terkait bentuk pendidikan dalam aspek iman, dalam aspek ibadah, dalam asppek moral dan aspek sosial. Kemudian tahap kedua adalah penyajian data, yakni meilih data yang masuk pada fokus penelitian dan membuang data yang tidak termasuk dalam penelitian ini. Serta yang terakhir yakni verifikasi data atau penarikan kesimpulan dari data yang terkumpul secara keseluruhan.

\section{HASIL}

Adapun hasil penelitian yang ditemukan setelah meneliti bentukbentuk pendidikan Islam bagi anak dalam rumah tangga di Desa Morella Kabupaten Maluku Tengah ditemukan bahwa ada beberapa aspek pendidikan yang dilakukan oleh orang tua dalam rumah tangga, yakni:

1. Pendidikan dalam aspek Iman terdiri dari:

a. Membuka kehidupan anak dengan kalimat Laa Ilaaha Illallaah, dengan berbagai cara:

1) Mengazani anak saat lahir, yakni orang tua memperdengarkan azan di telinga kanan dan iqamah di telinga kiri anak saat lahir. Jika tidak ada orang tua anak, aka kerabatnya, seperti kakeknya atau paman dari anak, namun hal iniang sekali terjadi. Yang sering terjadi adalah para Biyang (perannya sama dengan bidan) yang mengazani dan memberi iqamah anak ketika lahir.

2) Mentahnik anak, yakni dengan mengecapkan madu atau gula yang sudah dilarutkan sebelum ibunya menyusui, sampai anak terbiasa menghisap madu teersebut dan menyusu pada ibunya. Itu adalah salah satu cara alternatif yang biasa digunakan oleh 
para orang tua, karena orang tua jarang sekali menyediakan kurma saat akan lahiran. Namun belakangan ini, orang tua langsung menyediakan susu formula sebelum bayi menyusu pada ibunya. Ini terjadi pada orang tua yang terlambat sekali keluar air susunya.

3) Menyusui anak, yakni ketika anak sudah bisa menyusu pada ibunya, dalam kepercayaan masyarakat desa Morella, anak harus disusui terlebih dahulu dari sebelah kanan dengan membaca basmalah. Meskipun air susu sebelah kanan tidak mengluarkan susu. Sebab mengawali dengan kanan mengkonotasikan bahwa anak akan menjadi anak yang baik dan dikaitkan dengan akhlak yang baik-baik.

4) Menggunting/mencukur rambut atau aqiqah, yakni dilakukan saat anak baru lahir, atau 3 hari setelah kelahiran, atau 7 hari setelahnya. Ini yang terjadi pada umumnya. Kalaupun ada yang melewati waktu 7 hari, maka itu terjadi karena ada yang menunggu ayah si bayi atau kerabat dekatnya yang jauh di rantau untuk pulang pada saat guntung rambut/aqiqah.

Untuk masalah yang satu ini. Orang tua di desa Morella Kabupaten Maluku tengah tidak terbiasa melakukan aqiqah, kecuali orang tua yang memiliki tingkat ekonomi yang mapan. Namun untuk masayarakt biasa, hanya dilakukan dengan baca doa atau tahlilan seperti biasa, kemudian meggunting rambut bayi dan memberi nama dengan disertakan dengan melempar uang (istilah di desa: Rahuli' pisi) kepada anak-anak yang datang di depan rumah keluarga yang akikah sehingga mereka berebutan memunggul uang. Uang biasanya dalam bentuk logam. Sekarang sudah ditambah dengan permen.

Menurut data yang ditemukan, orang tua dulu dan sekarang berbeda dalam memberikan nama bagi anak. Jika orang tua dulu sering memberikan nama anaknya dengan nama-nama nabi atau 
keluarga nabi dan para sahabat, atau nama orang tua atau moyangnya si bayi yang memiliki kelebihan khusu, kalaupun tidak untuk sekedar dikenang, Orang tua sekarang lebih memilih nama artis, baik itu artis Arab, ataupun artis Indonesia, bahkan ada yang memberi nama artis Holliwood.

5) Khitan, yakni mengkhitan anak laki-laki pada usia tertentu sesuai dengan keadaan dan kemampuan orang tua. Jika orang tua mampu, khitanan biasanya diadakan dengan menyembelih hewan dan tahlilan serta rahuli pisi' sebagaimana yang terjadi di saat aqiqah. Tapi jika orang tua kurang mampu, biasanya mereka mengkhitan anaknya ketika ada khitanan masal.

b. Mengenalkan halal dan haram, biasanya orang tua mengenalkan yang haram atau yang tidak boleh dilakukan dengan tanda hukuman. Jika anak berbuat kesalahan, orang tua memukul kemudian mengajarkan jika hal itu bernilai negatif, memalukan diri dan kelurga dan lain sebagainya.

c. Membaca Al-Qur'an, Pendidikan ini awalnya adalah orang tua mengajarkan pengenalan huruf-huruf hijaiyah. Pengenalan awal diberikan ketika anak sudah dapat belajar membaca (sekitar usia 4-5 tahun). Pengenalan huruf hijaiyah pada usia ini bukan diajarkan dengan melihat buku/kitab iqra', namun dengan menghafal. Orang tua membacanya, kemudian anak mengikuti satu-persatu ucapan orang tuanya tanpa melihat seperti apa hurufnya. Pengajaran pada tahap awal ini dilakukan pada saat orang tua sedang duduk bersama anak-anak atau sebelum tidur. Akan tetapi pengajaran ini tidak dilakukan secara rutin setiap hari dan tidak diajarkan sekaligus semua huruf hijaiyah, namun beberapa huruf saja. Ketika anak sudah berusia 6 sampai 7 tahun, orang tua sudah menyerahkan anaknya ke TPA yang dipercayai, soal sampai dimana anak belajar mengaji, yang terpenting berangkat ke TPA. Ketika anaknya sudah 
sampai di bangku SMP, orang tua sudah mulai memberi keloggaran kepada anak. Tidak seketat usia tingkat dasar lagi.

2. Pendidikan dalam aspek ibadah:

a. Mengajarkan Shalat, terdiri dari dua bentuk, yakni ada orang tua yang mengajarkan anaknya sendiri mulai dari takbiratul ihram sampai salam dengan praktek langsung di hadapan orang tua, dan yang lainnya adalah mengajarkan anak untuk ke masjid melaksanakan salat. Entah anaknya sampai di masjid atau tidak, entah anaknya nanti main saja di dalam masjid, atau salatnya sembarangan, yang penting orang tua menyuruh anak untuk ke masjid. Untuk kasus ke dua ini, ada orang tua yang menanyakan anaknya saat sudah pulan dan ada juga yang tidak menanyakan apapun tentang bagaimana salatnya anak di masjid tadi. Inipun ada orang tua yang menyuruh secara rutin, ada orang tua yang sering menyuruh anak, ada lagi orang tua yang jarang sekali atau kadangkadang baru mengingatkan hal demikian kepada anaknya saat mereka teringat saja untuk menyuruh anaknya.

b. Berpuasa, biasanya diajarkan kepada anak ketika mereka sudah mulai memasuki sekolah dasar (sekitar 6-7 tahun). Ini diajarkan secara bertahap, yakni mulai diajarkan dengan cara makan sahur kemudian puasa hingga jam 10 pagi, hari berikutnya bertahan sampai jam 12 siang, berikutnya anak dibiasakan bertahan samapai jam 16 sore dan jika sudah mampu, anak diajarkan untuk bertahan hingga waktu berbuka. Ketika sudah sampai waktu berbuka, anak tidak lagi dibiarkan puasa hingga waktu siang saja, namun terus diperhatikan hingga berbuka bersama. Jika tidak sampai waktu berbuka, anak sering diberi hukuman tidak boleh ikut berbuka bersama dengan keluarganya yang berpuasa sehari penuh. Hal ini hanya berlaku untuk anak yang belum mumayyiz, bagi yang sudah tamyiz, dipaksakan orang tua untuk harus berpuasa selagi tidak berhalangan untuk anak perempuan. Untuk anak lelaki tidak ada 
pengecualian. Ketika sengaja tidak berpuasa, anak tidak diberi makan sehari penuh.

c. Memberi zakat (dalam hal ini zakat fitrah), pendidikan ini diberikan berbeda antara bayi dan balita (usia 0-2 tahun), kanak-kanan dan remaja. Bagi bayi dan balita, zakat mereka biasanya dibawakan ke orang yang mengurus kelahiran bayi (bahasa daerahnya: Mama Biyang), jika anak tersebut diurus oleh mereka saat lahir atau sesudah lahir. Karena di Desa Morella Kabupaten Maluku Tengah, setelah anak lahir hingga terlepas tali pusarnya, Mama Biyang-lah yang bertugas untuk mengurusi bayi, mulai dari memandikan, diberi kehangatan dengan api, hingga dipakaikan pakaian sampai anak tersebut terlepas tali pusarnya. Hal ini dilakukan agar anak tersebut menjadi anak yang kuat dan tidak gampang sakit ketika sudah besar. Bagi kanak-kanak (usa 6-12 tahun) diajarkan untuk memberi zakat kepada orang yang berjuang di jalan Allah, misalnya guru mengaji. Sehingga kebanyakan mereka membawa zakat mereka kepada guru mengajinya masing-masing. Namun untuk remaja, orang tua mengajarkan untuk memberi kepada fakir miskin, sehingga anak dalam usia ini sudah bebas memilih siapa saja yang ia rasa membutuhkan zakat tersebut. Kalupun anak kebingungan, barulah dia tanya kepada orang tuanya kira-kira siapa yang paling berhak menerima zakat, kemudian orang tua menunjukkan kepada anaknya kemana harus dibawa zakatnya tersebut.

3. Pendidikan dalam aspek moral meliputi:

a. Larangan bepergian, ini bukan berarti bahwa tidak boleh bepergian sama sekali. Anak diajarkan untuk meminta izin sebelum bepergian dan kembali pada waktu yang ditentukan orang tua. Ketika anaknya tidak kembali pada waktu yang ditentukan, maka orang tua yang datang menjemput anak. Ini berlaku bagi anak yangmasih berusia 4 sampai 12 tahun. Bagi anak yang remaja, orang tua kebanyakan hanya menanyakan kemana dan untuk apa anaknya pergi saja. 
Selebihnya ketika kembali ke rumah, anaknya tidak lagi ditanyakan apa saja perhal kepergiannya itu.

b. Berperilaku jujur, pendidikan ini diberikan saat oang tua kehilangan barang berharga. Anak ditanyakan dengan cara baik-baik perihal barang yang hilang itu ada yang ambil atau tidak. Dan ketika orang tua mencurigai benar bahwa anaknya yang mengambil, maka orang tua membuat hukuman dan perjanjian. Ada yang memukul dan ada yang disuruh memasukkan tangan ke air panas yang sudah diberi syarat tertentu. Jika berbohong (benar mencuri) tangannya akan melepuk, jika jujur (tidak mencuri) maka tangannya tidak melepuk. Sehingga anak harus benar-benar jujur mengambil atau tidak.

4. Pendidikan dalam aspek sosial:

a. Berbuat baik kepada orang tua, yaitu anak diajarkan untuk pandai membantu orang tua. Bagi anak yang masih kecil diajarkan untuk memberi salam dan bersalaman (mencium tangan) dengan orang tua sebelum dan kembali ke rumah rumah, mengajarkan anak untuk membantu mengambil barang-barang yang ringan misal membantu orang tua mengambil piring, baskom, untuk ibu, sedangkan untuk bapak, mengambil martil, obeng dan lain sebagainya. Untuk remaja, anak perempuan biasanya diajarkan untuk membantu orang tuanya dalam masalah rumah tangga, misalnya memasak, mengepel lantai, menyapu, membersihkan halaman rumah, disuruh belanja, dan mengantarkan orang tua dalam masalah-masalah tertentu. Untuk anak yang sudah remaja, orang tua sudah tidak lagi membiasakan si anak untuk bersalaman saat keluar dan kembali ke rumah, ini hanya digantungkan pada kesadaran anak sendiri. Jika mereka sadar untuk bersalaman maka ini disenangi, jika mereka tidak bersalaman lagi, tidak jadi masalah untuk orang tua.

b. Menjaga silaturahmi dengan sanak saudara, yakni pada awalnya anak diajarkan oleh orang tua untuk memanggil saudaranya dengan panggilan yang tepat, misalnya, Om (panggilan untuk saudara laki- 
laki dari lbu), Bibi/Uwa (panggilan untuk saudara perempuan dari ayah), Wate (panggilan untuk suami dari saudara perempuan ayah/suaminya Bibi), kemudian mengenalkan saudara-saudara dari orang tua kepada anak-anak mereka sehingga anak menjadi familiar dengan keluarga dari orang tuanya.

Dalam kebiasaan masyarakat desa Morella, keika ada anak yang berjalan kemudian bertemu dengan keluarga orang tuannya baik itu keluarga dekat maupun keluarga jauh kemudian si anak tidak menyapa mereka dengan panggilan di atas seperti Om, Bibi, Wate, Bapak, Mama, dan lain sebagainya, maka anak tersebut sudah dicap sombong oleh keluarga dari orang tuanya. Sehingga pendidikan pertama sekali yang adiajarkan oleh para orang tua di Desa Morella kepada anaknya adalah mengenali keluarga dan menyebut nama panggilan yang sopan. Kemudian orang tua mengingatkan kepada anak untuk selalu menyapa mereka dimana saja mereka bertemu.

c. Berbuat baik kepada tetangga, dengan cara yang menyuruh anak memberikan makanan kepada tetangga saat orang tuanya merasa lebih. Mengajak anak untuk menjenguk tetangga saat tetangganya sakit. Serta mengajarkan anak untuk membantu tetangga saat ada hajatan tertentu.

d. Menghargai orang yang lebih tua, pendidikan ini diajarkan kepada anak yang sudah memahami kata-kata orang tuanya, mulai 7 tahunan, dengan cara menunduk setengah badan saat melewati orang yang lebih tua. Jika orang tua sedang duduk bercerita, anak dilarang melewati depan orang tuanya, jika orang tuanya duduk di lantai, anak tidak boleh duduk di atas kursi atau tempat yang lebih tinggi dari orang tuanya, jika makan bersama orang tua, anak tidak boleh mengambil makanan sebelum orang tuanya mengambil duluan, anak tidak boleh berbicara jika orang tuanya belum selesai berbicara, anak tidak boleh bersuara melebihi suara orang tuanya. 
e. Etika memberi salam, diajarkan dengan cara memberi salam saat masuk dan keluar rumah sendiri dan rumah orang lain dengan suara yang sopan. Ketika anak disuruh orang tuanya untuk pergi ke rumah tetangga atau rumah orang lain untuk menyampaikan atau membawa sesuatu, anak sudah diingatkan untuk jangan lupa memberi salam sebelum masuk ke rumah orang.

f. Etika makan dan minum, diajarkan dengan cara mencuci tangan sebelum makan, duduk, dan makan dengan tangan kanan meskipun anaknya terbiasa tangan kiri (kidal). Untuk hal ini, anak jarang sekali diajkan untuk membaca doa sebelum anak memulai makan. Kalaupun diajarkan membaca doa itu hanya diajarkan pada anak berusia TK dan SD sja, ketika anak menginjak bangku SMP, sebagian besar orang tua sudah tidak lagi mengingatkan anaknya untuk membaca doa sebelum makan.

g. Memenuhi undangan teman, untuk bagian ini berbeda antara undangan kanak-kanak dan undangan remaja. Ketika anak berusia 2-12 tahun mendapatkan undangan temannya, orang tua mengantar anak di tempat hajatan dan menunggu hingga pulang bersama anak. Tapi bagi anak di atas usia 12 tahun, kebanyakan orang tua hanya mengantarkan saja ke lokasi hajatan, nanti ketika pulang, anaknya akan pulang bersama teman-temannya sendiri. Bahkan ada orang tua yang tidak lagi mengantarkan anaknya, melainkan anaknya pergi dan pulang bersama teman-teman mereka..

\section{PEMBAHASAN}

Pendidikan Islam adalah sebuah sistem yang menjadi wadah untuk menumbuhkembangkan potensi individu ke arah yang dicita-citakan Islam yakni menjadi insan yang beriman dan berakhlak mulia, yang dijiwai dan menjadi corak kehidupan kepribadiannya (M. Arifin, 2011: 7).

Karena pendidikan Islam merupakan sebuah sistem, sudah barang tentu memiliki komponen-komponen yang saling mendukung dan 
ketergantungan untuk mencapai tujuan pendidikan Islam tersebut, salah komponennya adalah alat pendidikan yang dapat menunjang kelancaran pendidikan itu sendiri (Zuhairini, dkk, 2009: 181). Barnadib (1984: 113) berpendapat bahwa alat pendidikan merupakan tindakan atau perbuatan atau situasi atau benda yang dengan sengaja diadakan untuk mencapai cita-cita akhir pendidikan. Dengan demikian alat pendidikan dapat berupa keteladanan, perintah, pembiasaan, larangan, nasehat, pengawasan dan hukuman.

Sebagai sebuah sistem, pendidikan Islam tidak akan mencapai tujuan akhirnya tanpa peranan yang penuh tanggung jawab oleh manusia yang menjalankannya. Sehingga setiap individu yang melewati tahapan kehidupan harus senantiasa dikawal pertumbuhan dan perkembangannya secara sempurna oleh orang-orang yang tinggal di sekitarnya. Setiap individu yang lahir ke dunia ini, orang pertama ditemui adalah orang tua yang menjadi madrasah pertama baginya. Meski pada kenyataannya ada orang tua yang tega membuang anaknya sendiri atau menitipnya ke panti asuhan dengan berbagai macam alasan untuk dibenarkan.

Sebagai orang yang telah diberi kudrat kasih sayang kepada anaknya, diperintahkan oleh Allah SWT. melalui QS Al-Tahrim ayat 6 untuk senantiasa menjaga keluarganya dari siksa api neraka. Ayat ini mengandung makna perintah tegas kepada orang tua untuk mendidik anaknya hingga dia dewasa. Dengan demikian maka mendidik anak adalah tanggung jawab terbesar yang diemban oleh setiap orang tua.

Abdullah Nashih Ulwan (2002: 157-607) mengemukakan bahwa ada enam tanggung jawab pendidikan orang tua kepada anaknya, yakni Tanggung jawab, pendidikan iman, pendidikan moral, pendidikan fisik, pendidikan rasio, pendidikan sosial, dan pendidikan seksual. Tanggung jawab ini dilaksanakan sejak anak mulai lahir hingga ia dewasa.

Pendidikan anak tentu berbeda antara usia 0-6, 7-12, dan 13-24. Karena setiap fase pertumbuhan memiliki ciri khas dan kebutuhan yang berbeda (Jalalluddin: 2010: 66-74). Meski tidak setiap orang tua 
memahami kebutuhan anak dalam setiap tahapan perkembangannya yang diakibatkan karena rendahnya tingkat pendidikan dan minimnya pengetahuan orang tua tentang hal itu, namun setiap orang tua memiliki tanggung jawab yang sama dalam mendidik anak-anaknya.

Dari hasil penelitian yang ditemukan di atas, pada umumnya orang tua di Desa Morella Kabupaten Maluku Tengah sudah menjalankan tanggung jawabnya sebagai pendidik pemula bagi anak-anaknya, mulai dari anaknya baru lahir hingga mereka berada di bangku SMA. Hanya saja pendidikan ini hanya merupakan pendidikan yang turun temurung didapatkan oleh para orang tua di Desa ini.

Pendidikan Islam yang murni dilakukan dari inisistiaf orang tua dalam rumah tangga hanya meliputi pendidikan salat, mengahargai orang tua dan orang lain, dan rajin belajar baik di sekolah maupun di rumah. Sehingga hal lain selain itu yang penulis dapatkan di lapangan hanya merupakan kebiasaan yang sudah turun temurung sehingga orang tua sekarang juga melakukan hal demikian pada anaknya. Misalnya mengazani dan iqamah pada telinga bayi saat lahir, mentahnik anak, aqiqah, khitan, mengajari kesopanan, dan lain sebagainya, ini sudah kebiasaan orang tua yang turun temurung. Ini terjadi karena rata-rata orang tua di desa ini memiliki tingkat pendidikan rendah yakni SD sampai SMP, serta kurangnya pengetahuan agama kepada anak dalam rumah tangga. Padahal, zaman ini orang tua sudah tidak lagi kesulitan mendapatkan informasi tentang mendidik anak dalam rumah tangga, karena banyaknya media kominasi dan informasi yang dapat digunakan untuk belajar dan mendalami ilmu agama.

Karena rendahnya pemahaman tentang pendidikan Islam bagi anak dalam rumah tangga, menyebabkan pendidikan orang tua kepada anak menjadi terputus antara anak berusia 12 ke 13 hingga dia dewasa. Usia remaja yang membutuhkan banyak perhatian dari orang-orang di sekitarnya tidak mendapat perhatian penuh dari orang tua ketika mereka telah duduk di bangku SMP hingga SMA. Masa remaja adalah masa 
dimana keyakinan anak terombang ambing, kadang-kadang berubahubah sesuai dengan pertumbuhan perasaan yang dilaluinya, karena itu, dukungan orang tua sangat memiliki arti besar terhadap kebutuhan perkembangan mereka (Daradjat, 2005: 35-66).

Orang tua begitu banyak mengajarkan anak ketika dia masih di bangku TK dan SD. Ketika mereka melewati jengjang itu, pendidikan menjadi longgar. Inilah alasan mengapa kondisi remaja di desa ini menjadi lemah dari sisi agama dan etika/moral, sebab orang tua merasa bahwa usia ini anak sudah dapat mandiri, tidak perlu banyak disuruh lagi toh dia bisa melakukan sendiri. Padahal justru di usia ini anak sudah butuh keyakinan dan ketetapan hati dari orang tua untuk istiqamah sehingga tidak terkontaminasi dengan gangguan yang ada di luar dirinya.

Selain kurangnya pemahaman, orang tua juga tidak termotivasi untuk mengikuti kajian ta'lim yang diselenggarakan oleh beberapa majelis ta'lim di desa ini dan tidak mengikuti kajian Islam yang ada di beberapa chanel televisi dengan alsan sibuk mengurusi pekerjaan rumah dan anak untuk kaum ibu, sementara untuk para bapak sibuk mencari nafkah.

Pada sisi yang lain, majelis ta'lim (bagi para ibu) yang ada di Desa Morella tidak diisi dengan materi kajian Islam terutama tentang pendidikan Isam bagi anak. Majelis ta'lim kebanyakan diisi dengan membaca barzanji, sehingga majelis ini lebih aktif saat tiba masanya maulid Nabi atau Isra' Mi'raj. Sedangkan majelis zikir (bagi para bapak) hanya beorientasi pada membaca al-Qur'an dan tahlilala, yasinan dan zikir bersama. Adapun majelis ta'lim yang diselenggarakan oleh jamaah tabligh hanya berkisar pada masalah ibadah dan muamalah, tidak menyentuh hal pokok tentang pendidikan anak.

Oleh karena itu, implekasi dari hasil penelitian ini adalah: 1) Tri kesadaran orang tua menjadi faktor utama dalam membenahi kualitas pendidikan bagi anak, yakni kesadaran untuk menjalankan ibadah dan akhlak sebagai uswah hasanah bagi anaknya, kesadaran menambah ilmu dari media mana saja tentang cara mendidik anak sehingga anak dapat 
didik sesuai kebutuhannya, dan kesadaran untuk mendidik anaknya hingga dia dewasa. 2) Majelis ta'lim dan majelis zikir tidak bisa dibatasi dengan barzanji, tadarus, yasinan, tahlilan dan zikir saja, namun perlu ditambah dengan kajian-kajian Islam terutama cara mendidik anak dalam rumah tangga. Jika kedua hal esensial ini berfungsi dengan baik, maka niscaya setiap anak yang ada di Desa Morella Kabupaten Maluku Tengah akan teratasi dari hal-hal negatif.

\section{KESIMPULAN}

Pendidikan Islam dalam rumah tangga di desa Morella Kabupaten Maluku tengah melipti pendidikan Iman, pendidikan dalam Aspek ibadah, pendidikan dalam aspek moral dan pendidikan dalam aspek sosial. Dalam keempat pendidikan tersebut, hanya ada sebagian kecil pendidikan yang murni diajarkan atas inisiatif masing-masing orang tua, yakni pendidikan ibadah, mencakup salat dan mengajar membaca al-Qur'an, selain dari pada itu, pendidikan yang dilakukan merupakan pendidikan yang sudah dilakukan secara turun temurung dari para leluhur sebelumnya. Hal ini terjadi karena kurangnya pemahaman orang tua tentang pendidikan Islam bagi anak dalam rumah tangga, serta kurangnya wadah pengembangan IImu pendidikan Islam di Desa morela kabupaten Maluku tengah. Dengan demikian, maka untuk mengatasi kekurangan yang dimiliki orang tua, maka perlu disediakan fasilitas pengembangan pengetahuan kepada orang tua terkait pendidikan Islamdalam rumah tangga.

\section{DAFTAR PUSTAKA}

[1] Ahmadi, Abu, Nur Uhbiyati. (2003). Ilmu Pendidikan. Cet. II. Jakarta: Rineka Cipta.

[2] Al-Munawwar, Said Agil Husin. (2005). Aktualisasi Nilai-nilai Qur'ani dalam Sistem Pendidikan Islam. Cet. II. Jakarta: Ciputat Press.

[3] Arifin, H. M. (2011). IImu Pendidikan Islam; Tinjauan Teoretis dan 
Praktis Berdasarkan Pendekatan Interdisipliner. Cet. V. Jakarta Bumi Aksara.

[4] Barnadib, Sutari Imam.(1984), Filsafat Pendidikan Islam. Yogyakarta: IKIP-FKIP GAMA.

[5] Daradjat, Zakiah. (2005).IImu Jiwa Agama. Cet. XVII. Jakarta: Bulan Bintang.

[6] Daulay, Haidar Putra.(2004). Pendidikan Islam dan Sistem Pendidikan Nasional di Indonesia. Cet. I. Jakarta: Kencana.

[7] Departemen Pendidikan Nasional. (2011). Undang-undang Republik Indonesia Tentang Sistem Pendidikan NasionalNomor 20 Tahun 2003. Cet. IV. Jakarta: Sinar Grafika.

[8] Faisal, Sanapiah.(t. th.)Sosiologi Pendidikan. Surabaya: Usaha Nasional.

[9] Jalaluddin. (2010) .Psikologi Agama. Jakarta: Raja Grafindo Persada.

[10] Nata,Abuddin. (2010). IImu Pendidikan Islam. Cet. I. Jakarta: Prenada Media Group.

[11] Room, Muhammad.(2010).Implementasi Nilai-nilai Tasawuf dalam Pendidikan Islam.Cet. III. Makassar: YAPMA Makassar.

[12] Shihab, M. Quraish.(2007). Wawasan al-Qur'an; Tafsir Tematik atas Pelbagai Persoalan Umat, Cet. I;.Bandung: Mizan.

[13] Ulwan, Abdullah Nashih. (1999). Tarbiyatu Al-Alwad Fii Al-Islam, Terj Jamaludin Miri.Jakarta: Pustaka Amani.

[14] Zuhairini, dkk.,(2009).Filsafat Pendidikan Islam. Cet. V; Jakarta: Bumi Aksara. 